\title{
THEORETICAL AND EXPERIMENTAL INVESTIGATIONS OF STRENGTH PROPERTIES OF CAST PARTS FOR FREIGHT CARS BOGIE WITH AXLE LOAD OF 245 KN
}

\author{
Valeriy Bubnov ${ }^{1}$, Sergey Myamlin ${ }^{2}$, Nikolay Mankevych ${ }^{3}$ \\ ${ }^{1,3}$ LTD “GSKBV” (PJSC “Azovmash”); 87535 Ukraine, Mariupol, Mashinostroiteley sq. 1 \\ ${ }^{2}$ Dnepropetrovsk National University of Railway: Transport named after Academician V. Lazaryana \\ 49010, Ukraine, Dnepropetrovsk-10, Lazaryana st. 2, University \\ E-mails: ${ }^{1}$ bubnov@azovmash.com,gskbv@mail.ru; ${ }^{2}$ myamlin@nzn.diit.edu.ua; sergeymyamlin@gmail.com; \\ ${ }^{3}$ gskbv@mail.ru
}

\begin{abstract}
The cast parts of bogies for freight cars are most loaded elements, which are subject to special requirements in view of the fact that their technical condition directly affects the safety of traffic. The most stressed parts of bogies include side frames and bolster. The paper describes the results of the calculation, static and fatigue strength tests of bolster and side frame for freight car bogie model 18-1711 with axel load of $245 \mathrm{kN}$. Structural analysis was made based on allowable stress and the safety factor of fatigue strength. Analysis of the results of the calculation, static and fatigue testing results proved that design of side frame and bolster comply with all normative documents. The result of the complex theoretical and experimental investigations have provided confirmation of the selected constructive solutions bolster and side frame for bogie with a axle load $245 \mathrm{kN}$, which confirms the possibility of their use in the manufacture of freight cars.
\end{abstract}

Keywords: static test, fatigue test, strength test, finite element method, bolster, side frame, freight car bogie, analysis of the results, normative documents.

\section{Introduction}

The cast parts of bogies for freight cars are most loaded elements, which are subject to special requirements in view of the fact that their technical condition directly affects the safety of traffic. The most stressed parts of bogies include side frames and bolster. It is on the strength properties of these parts in the first place depends on reliable operation of the cars. Special urgency this issue have taken recently, when the expanded range of three-piece bogie of freight cars and increased the number of producers. With regard to potential violations of unauthorized operation of the carriage of cargo in freight cars, in particular this applies to tanks, the problem of providing the necessary strength properties of cast parts carts becomes acute urgency.

Features redesign bogies, including side frames and bolsters, previously considered by the authors (Бубнов 2012a; Бубнов 2011; Бубнов 2012b; Бубнов 2012c). The main trend of improving designs of cast parts with the processing technology. Determined that the bolster and side frame of freight car bogie are details, the reliability of which causes traffic safety vehicles. Durability of these parts for a given level of reliability requires accurate knowledge of the state of stress in hazardous areas with existing and future conditions. This article presents the results of investigation of the strength characteristics of the bolster and side frame for bogie model 18-1711, also made compared of calculated and experimental results.

\section{Research Methodology}

Evaluation of the results was performed by the allowable stress. The calculations used the finite element method (FEM) using the program complex ANSYS. Modern computer technology allows the analysis of the stress-strain state of three-dimensional parts with complex geometric forms, to which are cast parts of freight cars bogies. However, a greater importance is the correct choice of the design scheme. On how close to the design scheme, and reflects the actual design work in terms of its operation, the accuracy depends on solving the problem and correct conclusions.

A breakdown of the individual elements is one of the most important operations of FEM, which depends on the accuracy and efficiency calculations. In the areas of special interest is used more dense grid.

In the investigation of the strength of parts truck parts FEM simulation models (Fig. 1) constructed in compliance with all the drawing nominal sizes were divided into three-dimensional finite elements tetraidal forms of 8-10 $\mathrm{mm}$. In areas exposed parts most common breaks in in use finite element size of $1 \mathrm{~mm}$. Combination and value of the loads acting on the elements of the bogie, calculated in accordance with the "Norms ..." (Нормы... 1996). I mode considered relatively rare combination of extreme loads. The main requirement for the calculation of the strength of this mode - to prevent the emergence of residual strain (damage) in the site or details. In manual I mode corresponds to jumping pull away 
heavy train, impact of cars in the maneuvers, including the dissolution of a marshalling humps, emergency braking in trains at low speeds.

a)

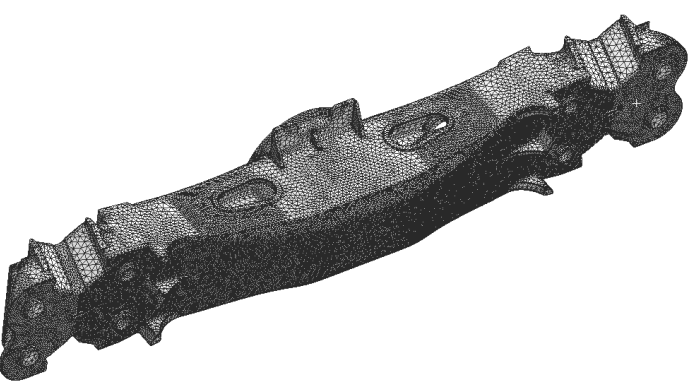

b)

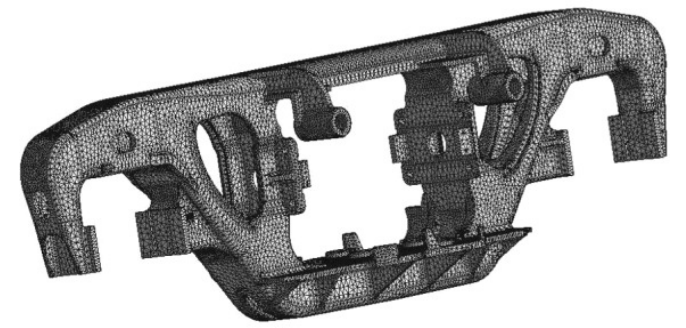

Fig. 1. Finite element model of bolster (a) and the side frame (b)

III mode was considered a relatively common possible combination of moderate size loads typical of normal operation of the car in a moving train. The main requirement for the calculation of the mode - to prevent fatigue failure of a node or detail. In the current operation mode III corresponds to the movement of the car in the train on the straight and curved sections of track and switches with the permissible speeds, up to structural speed, with periodic adjustment of service braking, periodic moderate jerks and pushes, staff work of the mechanisms and components of the car.

The main objective of the static strength tests was to investigate and evaluation of the static strength bolster and side frame of bogie under the influence of prescribed static loads that simulate the main design service loads.

In tests of the breaking load bearing capacity of performs checks bolster and side frame of bogie under the influence of standardized (limit) destroys loads (Надрессорные... 2010).

a)

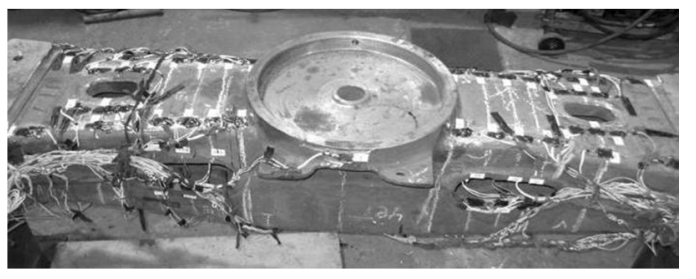

b)

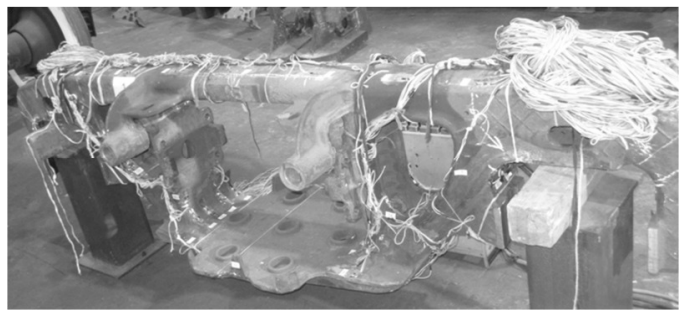

Fig. 2. Installing of strain sensors and measuring schemes mounting to bolster (a) and the side frame (b) of bogie model 18-1711
When static strength test is a comprehensive investigation of the strength of structures, validation and efficiency of design solutions, control the correctness of the calculation schemes used and the results of calculations by comparing them with the results of the tests. With this type of testing is important to select the right location for the installation of strain sensors for measuring the deformation which identifies stress in structural members of cast parts. Their installation (sticker) was carried out in waiting areas of greatest tension, and in the most important elements of which is directly related car traffic safety (Fig. 2).

\section{Calculation \& Testing Results}

Application of vertical, lateral and longitudinal loads to bolster and side frame for static strength test is shown in Fig. 3-5. Tables 1 and 2 show the values of the safety factor most crucial units bolster and side frame of bogie 18-1711 derived from the results of calculation and static strength tests. The discrepancy between the values of the safety factor defined by the results of FEM calculation and static strength tests in technological cutout and the jump ramp in the support surface bolster spring group, as well as in the lower edge of the opening angle of spring cutout of side frame can be explained by the fact that these elements are parts are areas of high stress concentration, which determine the deformation strain measurement method for static testing of natural samples is difficult (for example - radius of curvature to $5 \mathrm{~mm}$ ).

The discrepancies in the testimony of strain sensors and calculated results in other areas of no more than $10 \%$, which confirms the correctness of the calculation schemes. The stress in all investigated areas of bolster and side frame recommended by (Надрессорные... 2010), the results of calculations and tests did not exceed the allowable (Нормы... 1996), which indicates sufficient strength cast parts of bogie model 18-1711.

a)

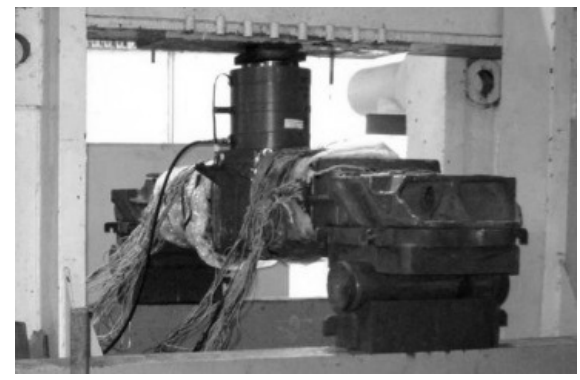

b)

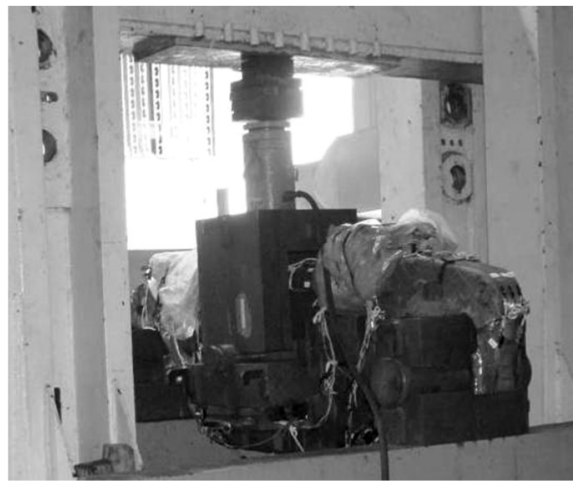

Fig. 3. Application lateral loads to bolster (a) and side frame (b) of bogie model 18-1711 
a)

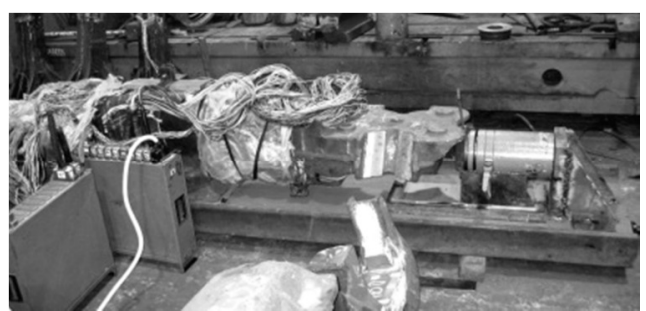

b)

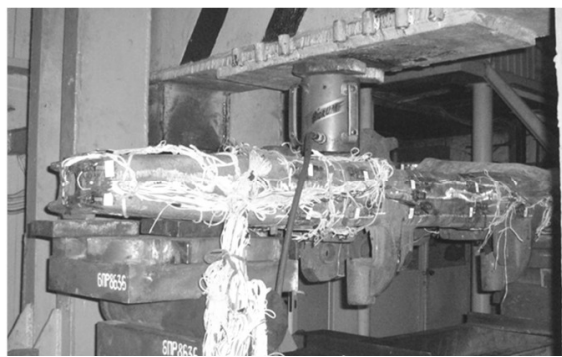

Fig. 4. Application of vertical loads to bolster (a) and side frame (b) of bogie model 18-1711

a)

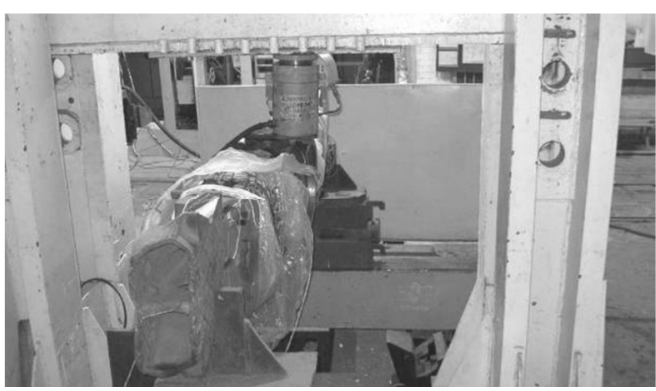

b)

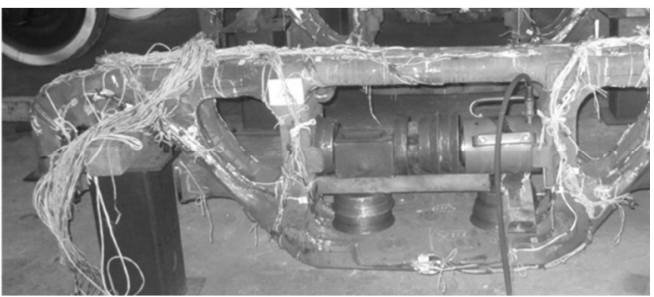

c)

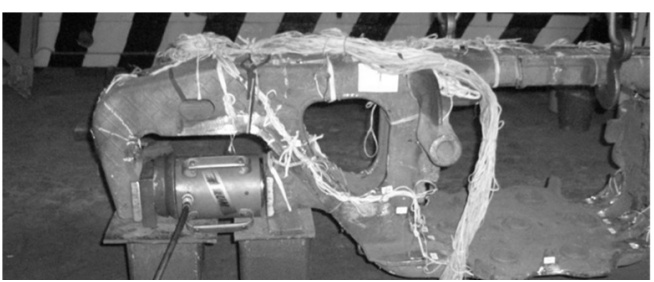

Fig. 5. Application of longitudinal loads to bolster (a) and side frame $(b, c)$ of bogie model 18-1711

Table 1. Comparison of calculation results and static strength tests of bolster

\begin{tabular}{|c|c|c|c|}
\hline \multirow{2}{*}{$\begin{array}{c}\text { The investigated } \\
\text { zone }\end{array}$} & \multicolumn{3}{|c|}{ Safety factor for allowable stress* } \\
\cline { 2 - 4 } & I mode & $\begin{array}{c}\text { I mode (dissolution } \\
\text { of a marshalling } \\
\text { humps) }\end{array}$ & III mode \\
\hline $\begin{array}{c}\text { The middle part of the } \\
\text { lower belt }\end{array}$ & $1.46 / 1.54$ & $1.27 / 1.35$ & $1.12 / 1.2$ \\
\hline $\begin{array}{c}\text { Technological cutout } \\
\text { of side rail }\end{array}$ & $1.17 / 1.72$ & $1.19 / 1.43$ & $1.18 / 1.57$ \\
\hline $\begin{array}{c}\text { The transition zone } \\
\text { incline in the support } \\
\text { surface ofspring group }\end{array}$ & $1.26 / 2.95$ & $1.27 / 2.35$ & $1.19 / 2.13$ \\
\hline $\begin{array}{l}* \text { In numerator value the results of the calculation, in denomi- } \\
\text { nator - the results of static strength tests. }\end{array}$ \\
\hline
\end{tabular}

Table 2. Comparison of calculation results and static strength tests of side frame

\begin{tabular}{|c|c|c|c|}
\hline \multirow{2}{*}{$\begin{array}{c}\text { The investigated } \\
\text { zone }\end{array}$} & \multicolumn{3}{|c|}{ Safety factor for allowable stress* } \\
\cline { 2 - 4 } & I mode & $\begin{array}{c}\text { I mode (dissolution } \\
\text { of a marshalling } \\
\text { humps) }\end{array}$ & I mode \\
\hline $\begin{array}{c}\text { Internal corner of } \\
\text { axlebox }\end{array}$ & $1.71 / 1.67$ & $1.18 / 1.17$ & $1.35 / 1.35$ \\
\hline $\begin{array}{c}\text { Outer corner of } \\
\text { axlebox }\end{array}$ & $4.1 / 4.43$ & $1.12 / 1.22$ & $-/-$ \\
\hline $\begin{array}{c}\text { Bottom corner of } \\
\text { the spring cutout }\end{array}$ & $1.23 / 1.74$ & $1.5 / 2.45$ & $1.11 / 1.54$ \\
\hline $\begin{array}{l}* \text { In numerator value the results of the calculation, in denomi- } \\
\text { nator - the results of static strength tests. }\end{array}$
\end{tabular}

After application of breaking loads to the bolster and the side frame (Fig. 6) value than the minimum allowed by the load (Надрессорные... 2010) by $26 \%$ and $11 \%$ respectively, cracks and damage on the parts not found, indicating that maintaining their load capacity.

Evaluation of fatigue strength of bolster and side frame was made on regulatory compliance (Бубнов 2012; НБ ЖТ ТМ 02-98), the results of the FEM calculations, as well as fatigue tests on the resonance vibrostand (Tables 3 and 4). The analysis was performed for the most common areas exposed breaks in in service.

a)

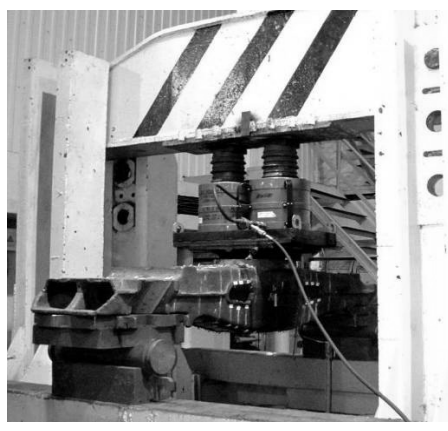

b)

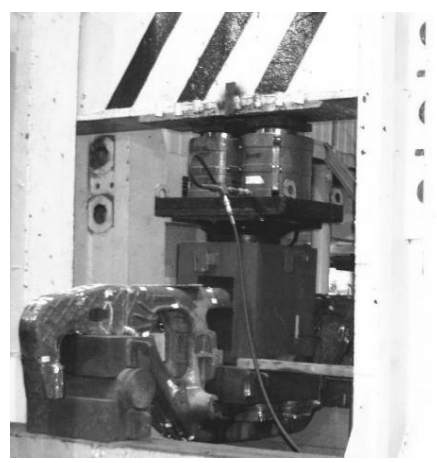

Fig. 6. Test of bolster (a) and the side frame (b) of bogie model $18-1711$ by the breaking load

Table 3. Evaluation of fatigue strength of bolster

\begin{tabular}{|c|c|c|c|}
\hline & \multicolumn{3}{|c|}{ Fatigue factor } \\
\cline { 2 - 4 } The investigated zone & calculated & $\begin{array}{c}\text { experi- } \\
\text { mental }\end{array}$ & $\begin{array}{c}\text { minimum } \\
\text { allowable (HБ } \\
\text { ЖT TM 02-98) }\end{array}$ \\
\hline $\begin{array}{c}\text { The middle part of the } \\
\text { lower belt }\end{array}$ & 2.24 & & \\
\hline $\begin{array}{c}\text { Technological cutout of } \\
\text { side rail }\end{array}$ & 2.26 & 2.05 & 1.8 \\
\hline $\begin{array}{c}\text { The transition zone } \\
\text { incline in the support } \\
\text { surface ofspring group }\end{array}$ & 2.29 & & \\
\hline
\end{tabular}


Table 4. Evaluation of fatigue strength of side frame

\begin{tabular}{|c|c|c|c|}
\hline \multirow[b]{2}{*}{ The investigated zone } & \multicolumn{3}{|c|}{ Fatigue factor } \\
\hline & calculated & $\begin{array}{l}\text { experi- } \\
\text { mental }\end{array}$ & $\begin{array}{c}\text { minimum } \\
\text { allowable (HБ } \\
\text { ЖТ TM 02- } \\
98)\end{array}$ \\
\hline Internal corner of axlebox & 2.56 & \multirow[b]{2}{*}{2.12} & \multirow[b]{2}{*}{1.8} \\
\hline $\begin{array}{l}\text { Bottom corner of the } \\
\text { spring cutout }\end{array}$ & 2.22 & & \\
\hline
\end{tabular}

\section{Conclusions \& Recommendations}

According to the results of theoretical investigations and tests, that design of bolster and side frame of bogie with $245 \mathrm{kN}$ axle load satisfies all regulatory requirements for strength and fatigue characteristics. Thus, as a result of the complex theoretical and experimental investigations have provided confirmation of the selected constructive solutions bolster and side frame for bogie with a axle load $245 \mathrm{kN}$, which confirms the possibility of their use in the manufacture of freight cars.

\section{References}

Бубнов, В. М. 2011. Проблемы прочности и надежности боковой рамы двухосной тележки грузовых вагонов / Бубнов В. М., Мямлин С. В., Манкевич Н. Б., Кононенко В. В. //Проблеми та перспективи розвитку транспортних систем в умовах реформування залізничного транспорту: управління, економіка і технологія: матеріали 5 міжнар. науковопракт.конф., 24-25 березня 2011 р., Київ. Сер. «Техніка, технологія». К.: ДЕТУТ, с. 20-22.

Бубнов, В. М. 2012а. Основные тенденции совершенствования ходовых частей грузовых вагонов / В. М. Бубнов, С. В. Мямлин. Н. Б. Манкевич // Проблеми та перспективи розвитку залізничного транспорту: тези доповідей 72 Міжнар. науково-практич. конф., 19-20 квітня 2012 р., Дніпропетровськ. Д.: ДНУЗТ, с. 74-75.

Бубнов, В. М. 2012b. Результаты испытаний рамы боковой и балки надрессорной тележки грузовых вагонов с осевой нагрузкой 25 тс модели 18-1711/ В. М. Бубнов, С. В. Мямлин. Н. Б. Манкевич // Проблеми механіки залізничного транспорту: тези доповідей ХІІІ Міжнар. конф., 23-25 травня 2012. Дніпропетровськ. Д.: ДНУЗТ. 95 с.

Бубнов, В. М. 2012c. Пути совершенствования прочностных характеристик ходовых частей грузовых вагонов рамы двухосной тележки грузовых вагонов / В. М. Бубнов, Н. Б. Манкевич, С. В. Мямлин // Вагонный парк. № 2, с.4-6.

Надрессорные балки и боковые рамы литые двухосных тележек грузовых вагонов колеи 1520 мм. 2010. Методика испытаний на прочность. ОАО «НИИ вагоностроения»-ОАО «ВНИИЖТ», М.

НБ ЖТ ТМ 02-98 «Металлопродукция для подвижного ж.д.состава. Нормы безопасности».

Нормы для расчета и проектирования вагонов железных дорог МПС колеи 1520 мм (несамоходных), с изм. и доп. 1996. М., ГосНИИВ-ВНИИЖТ. 319 с. 